\title{
PENCIPTAAN DESAIN BUSANA WANITA DENGAN SUMBER IDE LAGU DOLANAN
}

\author{
Widyabakti Sabatari \\ Jurusan Pedalangan, Fakultas Seni Pertunjukan, \\ Institut Seni Indonesia Denpasar, Indonesia.
}

\begin{abstract}
Dolanan anak or children's toys are considered as an effective method to improve the children's potential and creativity because it can simultaneously improve their body and soul all at once those are between physical exercise, intellect exercise, art exercise and emotional exercise. Besides becoming medium to give the culture values to the children, the songs can also be a medium to show them the musical values. Musical aspect that is often met in some specific games: vocal, singing in some games, such as cublak-cublak suweng, jaranan and soyang. It feels simple but the experience of singing actually gives the children a chance to perform and understand nondiatonic tones, in this case, the slendro and pelog tone arrangement in Javanese art. The giving of musical values which can 'go along' with these children's games is actually very strategic in the means to keep the character of the nation's culture, because with this generation after generation will not lose their ability to appreciate the culture inherited from their own nation.
\end{abstract}

Key words: Fashion design, the song dolanan, and education.

Pendidikan mempunyai peranan yang sangat menentukan bagi perkembangan dan perwujudan diri individu, terutama bagi perkembangan bangsa dan negara. Kemajuan suatu kebudayaan bergantung kepada cara kebudayaan tersebut mengenali, menghargai, dan memanfaatkan sumber daya manusia, hal ini berkaitan erat dengan kualitas pendidikan yang diberikan kepada anggota masyarakatnya, kepada peserta didiknya. Dalam konteks pengembangan sumber daya manusia Wardiman Djojonegoro dalam pengantar buku "Kreativitas, Kebudayaan dan Pengembangan Iptek", mengemukakan bahwa manusia sebagai aktor budaya memberikan makna dan arah terhadap bentuk-bentuk budaya lahiriah serta pembangunan itu sendiri. Perkembangan kebudayaan nasional diarahkan untuk memberikan wawasan budaya dan wahana pada pembangunan nasional dalam segenap 
dimensi kehidupan bermasyarakat, berbangsa, dan bernegara serta ditujukan untuk meningkatkan harkat dan martabat manusia Indonesia, memperkuat jatidiri dan kepribadian bangsa. Dalam hal ini, pendidikan merupakan wahana yang sangat penting dalam proses pengembangan kebudayaan nasional, karena pada dasarnya pendidikan itu sendiri merupakan proses pembudayaan. Pendidikan sebagai usaha sadar yang diarahkan untuk mengembangkan potensi peserta didik agar dapat diwujudkan dalam bentuk kemampuan, ketrampilam, sikap, dan kepribadian yang sesuai dengan tujuan pendidikan nasional. Di antaranya adalah mendorong berkembangnya kreativitas peserta didik, yang sejalan dengan perkembangan aspek-aspek yang lain seperti keimanan dan ketaqwaan, kecerdasan, ketrampilan, semangat kebangsaan, dan lain-lain, sehingga tercipta keseimbangan dan keselarasan (Supriadi, 1994:vi-vii).

Tujuan pendidikan pada umumnya ialah menyediakan lingkungan yang memungkinkan anak didik untuk mengembangkan bakat dan kemampuannya secara optimal, sehingga dapat mewujudkan dirinya dan berfungsi sepenuhnya sesuai dengan kebutuhan pribadinya dan kebutuhan masyarakat. Pada hakekatnya setiap orang mempunyai bakat dan kemampuan yang berbeda-beda, oleh karena itu memerlukan pendidikan yang berbeda pula. Pendidikan bertanggung jawab untuk memandu serta memupuk, mengembangkan dan meningkatkan bakat tersebut. Mengutip pendapatnya Renzuli tentang keberbakatan dikatakan bahwa, dulu orang biasa mengartikan "anak berbakat" sebagai anak yang memiliki tingkat kecerdasan yang tinggi, namun sekarang makin disadari bahwa yang menentukan keberbakatan bukan hanya inteligensi (kecerdasan), melainkan juga kreativitas dan motivasi untuk berprestasi (Utami, 2004:6). Kreativitas atau daya cipta memungkinkan penemuan-penemuan baru dalam bidang ilmu dan teknologi, serta dalam semua bidang usaha manusia lainnya. Kreativitas dapat muncul dalam setiap kegiatan manusia tidak terbatas dalam bidang seni, ilmu pengetahuan dan teknologi serta tidak terbatas pula pada tingkat usia, jenis kelamin, suku bangsa atau kebudayaan (Semiawan, 1987:7). Kreativitas secara naluri memang terkandung di dalam setiap manusia, walaupun dengan derajad yang berbeda. Pemahaman ini juga disepakati Todd I. Lubbart dalam buku Handbook of Creativity yang mengatakan "creativity can occur in virtually any domain, including the visual arts, literature, music, business, science, education, and everyday life (Sternberg ed.,1999:339). Salah satu kendala konseptual utama terhadap studi kreativitas adalah pengertian tentang kreativitas, alat-alat ukur yang digunakan, dan kesulitan me-rumuskan konsep kreativitas itu sendiri. Disadari bahwa sekarang ini hampir setiap orang, pemimpin lembaga kependidikan, manajer perusahaan, sampai pejabat pemerintah menganggap pentingnya kreativitas dalam usahanya untuk mengembangkan di sekolah, pekerjaan atau pun dalam pembangunan. 
Sejalan dengan pemikiran ini dan permasalahan yang sudah dikemukakan, maka fokus pembicaraan dalam tulisan ini adalah keinginan penulis untuk menyampaikan gagasan tentang pemanfaatan seni dan budaya dalam pembelajaran desain busana. yaitu menggunakan lagu-lagu dolanan atau lagu-lagu Jawa sebagai sumber ide dalam penciptaan desain busana wanita yang ditujukan untuk kostum grup vokal.

\section{PEMBELAJARAN BERBASIS BUDAYA}

Menurut Soemantri Brodjonegoro, setiap simpul seni dan budaya mewakili beragam tradisi dan budaya dari lingkungan wilayahnya. Disebutkan dalam Higher Education Long Term Strategy 2003-2010 dinyatakan bahwa seni yang berakar dari tradisi dan budaya lokal, merupakan faktor kritis dalam pengembangan karakter bangsa, serta pengembangan individu yang kreatif dan inovatif (Pannen, 2004:2). Pandangan ini membawa kita pada sebuah kenyataan, bahwa ditengah keberhasilan dunia pendidikan seni dengan hadirnya seniman-seniman yang sudah populer, yang mampu bersaing di tingkat nasional maupun internasional, terdapat isu yang kurang menyenangkan dan menjadi tantangan dunia pendidikan seni di Indonesia pada saat ini, yaitu semakin menurunnya apresisi dan upaya pelestarian kesenian klasik dan tradisional dari masyarakat, karena belum meratanya perhatian dan dukungan masyarakat terhadap seni. Seni dan budaya masih dipersepsikan banyak orang Indonesia sebagai suatu yang " eksklusif" hanya milik segelintir orang. Pada hal, seni dan budaya merupakan milik rakyat atau suatu komunitas budaya yang mengembangkan seni dan budaya berdasarkan kebutuhan dan kepercayaannya pada suatu masa untuk berinteraksi dengan alam dan mengekspresikan fenomena-fenomena tersebut. Ketika seni dan budaya menjadi eksklusif, seni dan budaya menjadi asing dalam komunitas budayanya sendiri, sebagaimana disinyalir dalam tulisan "Masyarakat kita sudah asing terhadap kebudayaannya sendiri" (Festifal Kebudayaan Melayu Serumpun)(Kompas, 19 Desember 2002). Oleh karena itu berbekal dari beberapa pendapat di atas, perlu kiranya sebuah pembelajaran yang berbasis budaya direalisasikan, karena merupakan suatu strategi pembelajaran yang mengintegrasikan seni dan budaya ke dalam pembelajaran bidang ilmu.

Dalam proses pembelajaran berbasis budaya, seni dan budaya berperan sebagai konteks tempat proses pembelajaran bidang ilmu terjadi, tempat pembelajaran diaplikasikan, dan sebagai media pembelajaran suatu bidang ilmu. Dengan demikian, seni dan budaya menyatu dengan pembelajaran bidang ilmu. Hal ini pula yang menjadikan seni dan budaya lebih mudah dimengerti, dikenal, dan diapresiasikan oleh berbagai masyarakat, tertutama dimulai oleh masyarakat sekolah formal. Disamping itu, menjadi hal yang sangat prospektif menjadikan bidang ilmu (yang dipelajari di sekolah) tidak 
asing dalam komunitas budaya, tetapi menjadi suatu bidang ilmu yang contextuialized. Pada akhirnya, kontektualisasi bidang ilmu diharapkan akan mampu mengembangkan seni dan budaya dalam suatu komunitas budaya (2004:3).

Pemanfaatn seni dan budaya dalam proses pembelajaran merupakan bentuk perwujudan pembelajaran yang kreatif, kontekstual, yang didasarkan pada prior cultural experience and knowledge yang dimiliki masing-masing siswa untuk mencapai hasil belajar yang bermakna, dan dapat mengubah suasana pembelajaran menjadi suatu pembelajaran yang menyenangkan, bermakna, kreatif, kontekstual, serta kontruktif. Pada saat bersamaan, pembelajaran tersebut juga memberikan kesempatan untuk mengenal dan mengpresiasikan seni dan budaya yang dimiliki oleh komunitas budayanya. Seperti yang dikemukakan Sal Murgiyanto, bahwa bidang ilmu hanya mementingkan olah tubuh dan olah pikir, tapi kurang diimbangi rasa keindahan atau olah rasa. Sebaliknya, kesenian cenderung meninggalkan kecerdasan, rasa lebih ditonjolkan. Oleh karena itu, pemanfaatan seni dalam pembelajaran akan memberikan alternatif yang lebih banyak lagi untuk berfokus pada olah tubuh, olah pikir, dan olah rasa pada saat yang bersamaan (2004:6).

Berkait dengan pemikiran ini dan seiring dengan judul tulisan di atas, kemudian penulis mencoba memahami dan mengaplikasikannya ke dalam pembelajaran desain busana, bahwa dengan memberi rangsangan tertentu misalnya berupa syair lagu, gambaran atau latar belakang lagu dan musik atau irama lagu, diharapkan bisa mengarahkan dan menghantarkan dalam penciptaan desain busana. Seperti diketahui bahwa sebuah lagu adalah sesuatu yang abstrak, oleh karena itu untuk mempercepat proses penciptaan, perlu kiranya diberikan suatu stimulan. Dalam proses pembelajaran selain kegiatan menggambar, mahasiswa dapat mengerjakannya sambil bernyanyi, sehingga suasana belajar menjadi lebih menyenangkan, bergairah sekaligus menjadi sarana untuk sadar budaya.

\section{DESAIN BUSANA WANITA}

Desain busana pada hakikatnya erat hubungannya dengan masalah mode, karena desain busana pada dasarnya adalah mencipta mode atau mencipta model pakaian (Kamil, 1986:9). Mode itu sendiri cabang dari seni rupa. Karya seni rupa mempunyai suatu desain yaitu suatu rupa yang dihasilkan karena susunan unsur-unsurnya. Unsur-unsur dalam suatu desain dijelaskan oleh Chodiyah dan Mamdy adalah susunan garis, bentuk, warna dan tekstur (1982:8). Menurut Graves (1951), unsur-unsur dalam desain dapat direduksi ke dalam beberapa faktor atau dimensi, yaitu garis, arah, bentuk, ukuran, tekstur, nilai dan warna. Agar unsur-unsur desain tersebut dapat disusun dengan menghasilkan efek tertentu, maka diperlukan prinsip- 
prinsip atau azas-azas desain, sedangkan penyusunan atau pengorganisasian dari unsur-unsur desain tersebut sering disebut juga komposisi (Suryahadi, 1989:19).

Ada beberapa prinsip desain yang dapat digunakan untuk menyusun unsur-unsur desain. Prinsip-prinsip tersebut antara lain: 1) Kesatuan atau unity; 2) Pusat perhatian atau emphasis atau center of interest; 3) Keseimbangan atau balance; 4) Proporsi; 5) Irama atau rhytm (Kamil, 1986: 60-66).

Tidaklah terlalu berlebihan apabila busana yang kita kenakan merupakan sarana untuk menyampaikan misi atau pesan kepada orang lain, atau dengan kata lain busana digunakan sebagai sarana komunikasi non verbal (Dharsono, 1992:1). Misi dan pesan tadi terpancar dari kepribadian yang tersirat dari cara berbusana, oleh karena itu busana dapat membuat "image" atau kesan pada waktu menampilkannya serta dapat mengundang reaksi bagi orang yang melihatnya. Menjadi tugas bersama untuk memakai dan menggunakan kesan tadi sebagai sarana penyampaian kepribadian, usia, jabatan atau sebagai apa keberadaannya di masyarakat dan lain-lain. Seperti halnya pendapat Hariani Mardjono yang mengatakan bahwa "Busana memperlihatkan siapa dia itu", maksudnya dengan busana-busana ini merupakan tolok ukur bagi martabat, kedudukan dari seseorang dalam masyarakat (Mardjono, 1991:2).

Pemilihan rancangan kostum yang tepat dan sesuai dengan keadaan si pemakai akan menambah nilai daya tarik sendiri, dan apabila memilih kostum yang dapat diterima oleh masyarakat dan lingkungan sekitar, sebaiknya tidak menyimpang jauh dari nilai-nilai kepribadian yang tercermin melalui estetika dan etika penampilan suatu tata krama dalam masyarakat. Hal ini mengingat bahwa sekarang berada dalam lingkungan masyarakat yang beragam dan keadaan yang penuh dengan perubahan-perubahan yang cepat sekali geraknya. Perubahan dalam dunia mode itu sendiri disebabkan adanya dinamika yang tumbuh dan berkembang dalam masyarakat, dengan pengaruh dinamika ini kita terdorong untuk mengikutinya. Namun untuk dapat lebih bijaksana dalam menentukan pilihan, sebaiknya mengenal diri sendiri terlebih dahulu, kemudian tahu apa yang diinginkan dan diperlukan. Menyadari bentuk tubuh sendiri adalah sangat penting, sehingga bila ada kekurangannya dapat ditutupi (dikamuflage). Seseorang yang tampil menarik berpenampilan menarik adalah salah satu kunci sukses seseorang dalam kehidupan masyarakat. Penampilan yang menarik bukanlah monopoli wanita cantik, dan setiap wanita mempunyai sisi yang menarik, tergantung pada wanita itu sendiri dalam pengembangan dirinya yang sebaik-baiknya, seutuhnya. Pernyataan ini juga disepakati oleh Ghea Panggabean yang mengatakan up to date itu harus, dan merupakan sebuah tuntutan dalam mode agar selalu trendi" (Daradjatun, Nunun dan Wattimena, 2003:14). 
Hal tersebut di atas tentu ditujukan untuk merancang kostum perseorangan atau individual. Dalam kelompok atau grup bisa saja rancangan kostum tersebut digunakan secara tunggal, manakala dikenakan oleh seorang penyanyi solis. Namun akan menjadi hal yang berbeda jika rancangan tersebut ditujukan untuk grup vokal yang tidak menggunakan penyanyi solis. Merancang kostumnya harus melihat dari berbagai sudut pandang dan banyak pertimbangan, yaitu syair dan latar belakang lagu, kesempatan pakai (untuk pentas atau lomba), waktu pemakaian (pagi, siang, sore atau malam hari), keserasian dengan back ground (jalannya pernafasan) serta anggaran yang tersedia.

Berkaitan dengan berbagai hal yang sudah dikemukakan sebelumnya, maka yang menjadi titik perhatian adalah bagaimana menampilkan sebuah rancangan kostum untuk grup vokal dan memadukannya dengan pelengkap kostum serta keserasian yang menyeluruh dari rambut sampai make-up. Untuk mencapainya perlulah menerapkan prinsip-prinsip desain dengan baik.

Membicarakan penampilan tidak lepas dari masalah pembawaan lagu dan latar belakang lagu. Keberhasilan suatu grup vokal akan maksimal apabila lagu tersebut dibawakan dengan "pas" sesuai dengan permintaan seorang komponis. Dalam tulisan ini akan difokuskan pada lagu-lagu Jawa atau nyanyian rakyat. Nyanyian rakyat merupakan bagian dari tradisi yang sudah diwariskan secara turun temurun, dan menjadi milik bersama baik dalam bentuk lisan, sebagian lisan maupun bukan lisan. Tradisi seperti itu disebut folklor (Harjawiyana dalam Soedarsono ed., 1986:477). Menurut James Danandjaya (1984: 2) folklor adalah sebagian kebudayan suatu kolektif, yang tersebar dan diwariskan turun-temurun di antara kolektif macam apa saja, secara tradisional dalam versi yang berbeda-beda, baik dalam bentuk lisan maupun contoh yang disertai gerak isyarat atau alat bantu pengingat. Termasuk dalam folklor lisan adalah bahasa rakyat, ungkapan tradisional, sanjak rakyat, cerita prosa rakyat, dan nyanyian atau lagu-lagu rakyat (Murniatmo dalam Soedarsoso ed., 1986: 4). Dijelaskan oleh Harjawiyana bahwa nyanyian rakyat dalam masyarakat Jawa dikenal dengan istilah tembang dolanan atau lagu dolanan. Nyanyian rakyat itu merupakan milik bersama, oleh karena itu terdapat variasi kata-kata atau lirik dalam penyebarannya, maksudnya lagunya sama tadi kata-katanya berbeda. Bentuk yang dominan dalam nyanyian rakyat adalah perulangan bentuk ulang, baik terlihat pada nama judul nyanyian maupun kata-kata dalam nyanyian tersebut (1986: 478). Syair lagu-lagu Jawa pada umumnya terdapat parikan yang tidak ubahnya sebagai pantun kesusasteraan Indonesia, yang digunakan untuk melukiskan perasaan asmara, sindiran-sindiran, lelucon-lelucon dan sebagainya yang lazim diucapkan sehari-hari dan sudah menyebar di kalangan masyarakat. 
Menurut Widyatmanta, parikan dalam satra Jawa kira-kira sama dengan pantun dalam bahasa Indonesia, yaitu baris-baris kalimat (ungkapanungkapan) yang mengandung sampiran dan isi, dengan memperhatikan (menekankan) purwakanthi swara (sajak) pada setiap barisnya (2002: 48). Dalam penjelasannya disebutkan bahwa parikan dapat dibedakan menjadi tiga, yaitu: (1) Parikan harian, parikan yang bentuknya tidak lengkap hanya berupa sampiran karena isinya orang yang diajak bicara dianggap sudah mengerti; (2) Parikan dengan aturan (lamba), terdiri dari dua baris. Baris pertama berisi sampiran, baris ke dua isinya, setiap kalimat dengan penggalan 4, 4 suku kata; (3) Parikan dengan aturan (rangkep), terdiri dari dua baris. Baris pertama sampiran, baris ke dua isi, dengan penggalan 4, 8 suku kata. Pendapat ini juga disepakati oleh Haryana Harjawiyana dalam buku" Kesenian, Bahasa dan Folklor Jawa"yang mengemukakan bahwa purwakanthi 'persajakan' mempunyai peranan penting dalam khasanah sastra Jawa, terutama pada nyanyian rakyat yang biasa disebut dengan lagu dolanan. Ciri purwakanthi adalah mudah dikenali dan diingat kanak-kanak. Adapun ciri pokok purwakanthi swara, ialah bunyi vokal (v-v), vokal konsonan (vk-vk), atau konsonan (kvk-kvk). Purwakanthi swara merupakan purwakanthi yang paling banyak terdapat dalam nyanyian rakyat, karena paling mudah dikenali dan diciptakan dibandingkan dengan purwakanthi lainnya, yaitu purwakanthi sastra dan purwakanthi lumaksita (Soedarsono, 1986: 484-485). Penggunaannya dapat dilakukan dengan melagukan atau dapat juga dengan menyelipkan dialog-dialog untuk mewarnai pembicaraan. Dengan demikian pendengar akan merasa senang mengikutinya, dan suasana menjadi ramai serta menyenangkan. Parikan tidak hanya terdapat dalam gendhing-gendhing Jawa dan lagu-lagu dolanan (permainan), melainkan juga didendangkan oleh penyanyi-penyanyi lagu keroncong, folksong bahkan oleh paduan suara.

\section{SUMBER IDE DAN TEKNIK PENYAJIAN GAMBAR}

Secara garis besar sumber ide dapat dikelompokkan menjadi tiga, yaitu: (1) Sumber ide dari pakaian penduduk dunia atau pakaian daerah Indonesia; (2) Sumber ide dari benda-benda alam seperti bentuk dan warna dari tumbuh-tumbuhan, binatang, gelombang laut, bentuk awan dan bentukbentuk geometris; dan (3) Sumber ide dari peristiwa Nasional maupun Internasional misalnya: pakaian olahraga dari peristiwa Asian Games, ide pakaian upacara 17 Agustusan. Semua yang ada di sekitar kita, suatu peristiwa atau benda-benda dapat dipakai sebagai sumber ide untuk menciptakan desain busana (Chodijah \& Wisri A.M., 1982: 172). Dalam penjelasan selanjutnya dikatakan bahwa apabila mengambil salah satu sumber ide tersebut tidak perlu secara keseluruhan, melainkan dapat diambil pada bagian-bagian tertentu yang dianggap menarik atau memiliki 
kekhususan atau keistimewaan, misalnya warnanya, kemudian dikembangkan menjadi sesuatu yang diinginkan. Pendapat yang serupa dikemukakan oleh Sri Ardiati Kamil bahwa untuk penciptaan desain yang baru dapat digunakan beberapa sumber, antara lain : (1) Sumber Sejarah dan Penduduk Asli; (2) Sumber dari Alam; (3) Sumber dari Pakaian Kerja ( 1986: 30-33). Akhirnya dapatlah dipahami bahwa kedua ahli di atas sependapat, apapun yang ada di alam ini termasuk kejadian alam bahkan sebuah lagu dapat menjadi sumber inspirasi dalam penciptaan desain baru.

Menurut Mark Mooring seorang designer yang berbakat pada Bergdorf Goodman di New York seperti yang dikutip oleh Kamil berpendapat bahwa dalam menciptakan model suatu busana yang baru melalui beberapa langkah, yaitu: (1) membuat busana asli dengan bahanbahan tekstil masa kini dan disebarkan ke pasaran menurut musim yang sesuai dengan busana yang diciptakan; (2) mengambil ide dari salah satu bagian yang asli dan diperbaharui. Misalnya, pada bagian lengan, garis leher (neckline), atau sebagian dari suatu embroidry; (3) mempelajari sejarah dari busana yang bersangkutan dan menikmati keindahan dari busana tersebut. Setelah itu detail-detail yang pasti dilupakan. Kemudian mulai dengan menciptakan koleksi baru tanpa meniru model aslinya (1986: 30). Untuk belajar membuat desain lebih dulu mempelajari sejarahnya, kemudian baru membuat busananya dengan sumber bermacam-macam masa dalam sejarah.

Menurut Hartatiati Sulistio, penampilan kreasi baru merupakan perpaduan antara teori desain busana, teknik menggambar, dan sumber ide. Tiga faktor ini merupakan faktor penentu karya cipta kreasi baru. Kreasi baru merupakan modifikasi bentuk lama pengamatan suatu benda atau busana tradisional menjadi suatu ciptaan baru dengan harapan menjadi perhatian masyarakat dan akan dipakai oleh mereka (2006: 104). Keberhasilan pengembangan ide serta kreasi desain juga didukung dengan pengetahuan yang lain seperti: sejarah busana, pengetahuan tekstil, teknologi busana, dan teknologi menjahit. Tentu untuk mewujudkan dalam karya tidak mudah, diperlukan sebuah kreativitas, seperti yang dikemukakan oleh Nunun Daradjatun bahwa kreativitas memang tanpa batas. Ia menjelajahi alam pikiran yang gaib, yang mampu membuat kejutan yang tak terduga, tetapi sebuah kreativitas akan menemukan maknanya yang sejati, manakala berakhir pada nilai-nilai universal: keindahan, kebenaran dan kebaikan (Daradjatun, Nunun \& Samuel Wattimena, 2003)

Telah dikemukakan sebelumnya bahwa sumber ide dalam tulisan ini adalah lagu dolanan. Dipilihnya lagu dolanan dalam upaya untuk ambil bagian dalam pembangunan masyarakat yang memandang manusia sebagai subyek pembangunan, maksudnya mendudukkan manusia dalam partisipasinya bagi upaya peningkatan kualitas bangsa disertai dengan berbagai pertimbangan. Pertama, sebagai alat pengembang kreativitas. Seperti disampaikan oleh Ki Supriyoko bahwa keberadaan "dolanan anak" 
relevan dengan pesan-pesan yang ada pada Convention on The Rights of The Child atau KHA (Konvensi Hak Anak) dan Forum Komunikasi Pembinaan dan Pengembangan Anak Indonesia (FK-PPAI) dalam upaya pengembangan potensi dan kreativitas anak di Indonesia. Dolanan anak atau permainan anak diakui sebagai metode yang efektif untuk mengembangkan potensi dan kreativitas anak, karena secara simultan bisa mengembangkan raga dan jiwa anak sekaligus, yaitu antara olah raga, olah pikir, olah seni dan olah rasa. Dolanan anak merupakan seni terapan (appropriate art), dalam arti aktivitas yang menghasilkan nilai dan fungsi; bukan seni murni (fine art) dalam arti seni untuk seni. Orang yang melihat dolanan anak akan merasakan keindahan di dalamnya, sedangkan anak-anak yang ber"dolanan" akan memetik hasilnya berupa kesehatan, ketrampilan, kecerdasan dan kepuasan. Keseluruhan itu dapat termanifestasikan dalam fungsi "dolanan anak", yaitu : fungsi rekreatif, membina fisik, melatih ketrampilan, melatih ketelitian, melatih keseksamaan, mengasah konsentrasi, belajar berkesenian, belajar berkompetisi serta belajar menterjemahkan pesan-pesan moral. Teji, jaranan, padang mbulan, ilir-ilir, cubllak-cublak suweng, merupakan dolanan anak yang berfungsi untuk belajar berkesenian dan belajar menterjemahkan pesan-pesan moral (Krisdyatmiko (ed.), 1999: 50-51). Pandangan ini juga dikemukaan oleh Seto Mulyadi selaku pakar psikologi anak dan praktisi dolanan anak, bahwa ada tujuh manfaat bermain anak, yaitu manfaat fisik, edukatif, kreatif, pembentukan konsep diri, sosial, moral dan sebagai terapi. Perkembangan kreativitas anak sangat dipengaruhi oleh berbagai rangsang-rangsang mental yang kaya sejak dini. Di samping itu dikemukaan pula dalam penjelasannya, bahwa seni musik mampu membentuk intelegensi anak. Menggeliti seni musik tingkat kecerdasan otak anak lebih bisa meningkat dibanding dengan anak yang tak pernah menyentuh seni. Melalui musik, beban anak dengan beragam tugas yang harus dikerjakan bisa terkurangi, serta memiliki nilai hiburan dan membawa imajinasi anak untuk rekreatif sesuai yang diangankan (1999: 7).

Kedua, sebagai media untuk menanamkan nilai budaya. Mengutip pendapat Edi Sedyawati yang menyebutkan bahwa dolanan anak disamping sebagai media untuk menanamkan nilai budaya, juga dapat dijadikan sebagai wahana penanaman nilai-nilai musikal. Aspek musikal yang seringkali ada dalam permainan-permainan tertentu. Vokal, nyanyian seperti dalam permainan cublak-cublak suweng, cempa ya rowa, sluku-sluku bathok, jaranan dan ilir-ilir. Terasa sederhana, namun pengalaman menyanyikan sebenarnya memberikan kesiapan pada si anak untuk mengapresiasikan dan menghayati nada non-diatonis, dalam hal ini sistem nada slendro dan pelog dalam kesenian Jawa. Penanaman nilai-nilai musikal yang dapat" menumpang" pada permaian anak ini sebenarnya amat strategis dalam upaya untuk mempertahankan jati diri budaya bangsa, karena dengan demikian generasi demi generasi tidak akan kehilangan kemampuan untuk menghayati 
warisan budaya dari bangsanya sendiri. Dengan kata lain, meskipun kita mahir dalam bernyanyi dan bermusik dengan menggunakan sistem nada diatonik, tidak akan meminta "trained incapacity", yaitu karena keterbiasaan pada sistem nada diatonik saja maka menjadi tidak mampu menangkap dan mengekspresikan musik dengan nada sistem nada yang lain, yang sebenarnya merupakan warisan budayanya sendiri (1999:47-48). Dijelaskan juga oleh Ki Hadisukatno bahwa dolanan anak yang bersifat tradisional ada yang berupa permainan dengan lagu dan gerak wirama . Permaian dengan lagu dan wirama banyak sekali ragamnya, misalnya: jamuran, cublak-cublak suweng, bibi tumbas timun, manuk-manuk dipanah, tokung-tokung, blarakblarak sempal, bang-bang-tut, pung-irung, bethu thonthong, kidang talon, ilir-ilir karya Sunan Kalijaga, dan lain sebagainya. Disamping itu masih terdapat jenis permainan yang lain seperti, permainan yang bersifat menirukan perbuatan orang dewasa, permainan untuk mencoba kekuatan dan kecakapan, permainan melatih panca indera, dan permainan dengan latihan bahasa (1999:5).

Telah dikemukakan terdahulu bahwa sumber ide dari penciptaan desain kostum akan difokuskan pada lagu-lagu dolanan, atau jenis lagu-lagu yang diambil dari permainan anak tradisional Jawa yang dapat dinyanyikan dan dibawakan dengan gerakan-gerakan dan jenis lagu-lagu Jawa yang didalamnya parikan yang mengandung pesan-pesan moral.

Secara garis besar permainan anak tradisional Jawa dapat dibagi menjadi dua kelompok, yaitu kelompok yang bersifat kompetitif dan rekreatif (Marsono et al., 1999: 12). Kata permainan dalam bahasa Indonesia, dikenal dengan istilah dolanan dalam bahasa Jawa. Dalam bahasa Inggris dibagi menjadi dua, yaitu play dan game (Ahimsa Putra, 1999: 13). Kata game dapat diterjemahkan menjadi "pertandingan", artinya cenderung bersifat kompetitif, berhadap-hadapan untuk saling bersaing, sedangkan kata play didefinisikan sebagai "bermain", atau "permainan untuk bermain" yang bersifat rekreatif. Kata rekreatif merupakan kata sifat yang berasal dari kata dasar rekreasi. Rekreasi mengandung arti "sesuatu yang menggembirakan hati dan menyenangkan seperti hiburan"(Tim Penyusun Kamus Pusat Pembinaan dan Pengembangan Bahasa, 1990: 738). Mengacu pada pendapat di atas, maka permainan anak-anak yang bersifat rekreatif sama artinya dengan permainan dalam arti play, dolanan, bermain sebagai sesuatu yang menggembirakan hati. Permainan anak tradisional yang bersifat kompetitif adalah jenis permainan yang masing-masing pelakunya saling berkompetisi/bertanding untuk menang.

Sebuah lagu merupakan hal yang abstrak, untuk memperoleh gambaran isi lagu perlu alat bantu guna mengarahkan perancang dalam mengambil ide untuk me-wujudkan karyanya. Sebagai upaya untuk memvisualisasikan penulis menggunakan busana adat pakaian Daerah Istimewa Yogyakarta untuk wanita bekerja atau bepergian, syair lagu 
dolanan dan syair lagu Jawa. Anak-anak pada zaman dahulu khususnya anak-anak perempuan di pedesaan, pada saat bermain atau bekerja membantu orang tua mengenakan kain batik dengan baju kebaya yang beraneka ragam motifnya sesuai dengan pilihannya, pada umumnya dengan motif kembang dan berwarna cerah. Cara mengenakannya kain agak tinggi di atas tumit (cingkrang, Jawa), maksudnya agar memudah gerak mereka (Wibowo, 1990: 31). Berkaitan dengan tulisan ini, maka pakaian yang digunakan sebagai sumber ide adalah pakaian orang dewasa bukan pakaian anak-anak.

Pakaian orang dewasa dan orang tua, untuk bekerja maupun bepergian di daerah Yogyakarta terdiri atas beberapa bagian, yaitu: sanggul, baju kebaya dari bahan lurik atau kain batik bermacam-macam motif. Kebaya memakai kuthu baru atau tidak, bengkung setagen dan kemben, selendang lurik atau batik. Selendang dipergunakan secara bervariasi, mengenakan alas kaki sandal atau kadang-kadang tidak, kepala bersanggul gelung kondhe dengan perlengkapan tusuk kondhe, dan sunggaran sekedarnya (1990: 34). Dalam bahasa Jawa kuno kata lurik berasal dari kata lorek yang berarti lajur atau garis, belang dan dapat pula berarti corak. Kain lurik adalah sehelai kain yang bercorak garis-garis searah panjang kain yang disebut lajuran, dan yang searah lebar kain pakan malang, sedangkan corak kotak-kotak kecil disebut dengan istilah cacahan. Khususnya di Jawa Tengah dan Jawa Timur dinamakan kain lurik (Djoemena, Nian S.,2000: 31).

Adapun lagu-lagu dolanan yang dipilih adalah cublak-cublak suweng, jaranan, dan soyang, sedangkan latar belakang lagu akan dijelaskan secara singkat berikut ini

\section{Cublak-cublak Suweng}

Permainan cublak-cublak suweng merupakan salah satu permainan yang bersifat rekreatif. Hal ini terlihat tidak adanya pemain yang bertanding untuk memperoleh kemenangan. Permainan cublak-cublak suweng berasal dari kata cublak-cublak yang berarti diketuk-ketuk, dan suweng yang berarti subang antik yang terbuat dari tanduk atau uwer (Ariani, 1997/1998: 95). Uwer dapat pula berarti subang dari daun kelapa muda (Prawiroatmodjo, 1957: 731). Dalam Baoesastra Djawa juga disebutkan bahwa uwer atau oewer dalam bahasa Jawa krama-ngoko, yaitu goeloengan soewiran djanoer (godong gedang) dianggo neseli leng pasoewengan soepojo melar (Poerwadarminta, 1939: 448). Berdasar pada asal kata tersebut, cublakcublak suweng berarti suatu permainan tradisional anak-anak yang pelaksanaannya dengan cara mengetuk-ketuk alat permainannya yang berupa subang atau uwer atau biji-bijian atau dapat pula berupa kerikil di telapak tangan para pemain. Permainan ini sangat populer di Daerah Istimewa Yogyakarta juga di wilayah Jawa Tengah, karena nama permainan tersebut yang mudah dikenali dan diingat. 
Pemilihan jenis permainan cublak-cublak suweng didasari atas dasar pertimbangan-pertimbangan, yaitu: 1) menggunakan perlengkapan permainan yang sangat sederhana dan dapat ditemukan di mana saja, yang berupa kerikil atau uwer; 2) dalam pembawaan lagu dapat menggunakan gerakan-gerakan sederhana yang dapat menambah daya tarik supaya lebih ekspresif. Gerakan-gerakan sederhana yang dapat dibawakan, antara lain dengan mengangkat kedua tangan di depan dada dengan posisi jari tangan menggenggam dan jari telunjuk tegak lurus saling digesek-gesekkan pada saat menyanyikan lagu sir sir pong dhele gosong.

Pembahasan tidak menitikberatkan pada proses atau cara jalannya memainkan permainan cublak-cublak suweng, akan tetapi bagaimana sebaiknya permainan itu dibawakan dalam lagu (dinyanyikan) dengan baik, menggunakan kostum yang menarik perhatian tanpa mengganggu pernapasan pada saat menyanyi, dan pesan lagu dapat diterima oleh penonton dengan mengesankan. Berikut ini lirik lagu cublak-cublak suweng yang diambil dari buku Bolelebo: Kumpulan Lagu Daerah (Widyawan, 1992: 36)

Cublak-cublak suweng

Suwenge ting gelenter

Mambu ketundung gudel

Pak empong lera-lere

Sapa ngguyu ndhelikake

Sir-sir pong dhele gosong

Sir-sir pong dhele gosong

\section{Jaranan}

Jaranan, berasal dari bahasa Jawa yang berarti tetironing jaran, dolanan ngemba-emba jaran (Sudaryanto \& Pranowo, 2001: 354). Dalam bahasa Indonesia berarti kuda tiruan atau permainan yang menirukan gerakgerik kuda. Dalam membawakan lagu jaranan, dapat dengan menggunakan gerakan sederhana seperti menirukan orang mencambuk kuda (jedher), menghentakkan kaki (gedebug). Sehubungan dengan hal ini, kostum yang dikenakan hendaknya tidak mengganggu gerak penyanyi, dirancang dengan memberi keleluasaan gerak. Lirik lagu jaranan diambil dari buku Mengenal Lagu-lagu Daerah (Tim Pustaka Widyatama, 2006: 19).

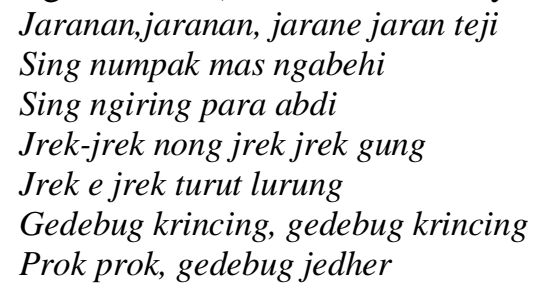

\section{Soyang}


Soyang merupakan salah satu permainan yang prosesnya melatih anakanak untuk belajar berbahasa Jawa dengan berbagai macam stratifikasinya, sehingga dalam permainan ini anak-anak dapat melatih diri untuk menggunakan bahasa krama, madya, dan ngoko lengkap dengan tata krama secara bebas dengan teman-teman sebayanya. .

Walaupun belum ditemukan secara pasti tentang rentetan sejarah yang dapat dipakai sebagai penyebab munculnya permainan ini, namun pada dasarnya soyang juga merupakan role playing permainan peran. dengan aturan main dan dialog yang sudah ditentukan. Permainan ini merupakan jenis permainan yang menggambarkan drama dua babak yang mengisahkan penyerahan anak-anak si mbok kepada lurah( Marsono, 1999:197-199). Adapun lirik lagu soyang ditulis oleh Sindu S. yang telah ditulis ulang oleh Damodoro Nuradyo dari kumpulan lagu-lagu Pilihan Bebas Lomba Paduan Suara Antar Perguruan Tinggi se Indonesia Tahun 1994 Universitas Gadjah Mada

Soyang, soyang bathik plangi dul semarang ya ya bu ya ya pa Manuk endra, kawanatus kawandasa, e kawula ngenger

Ngenger pisan sandhang pangan luru dhewe mondhok kecenthok kula nuwun jenggleng Sinten niku ndodog lawang kori, kula kengkenane Jainata

Kula nuwun, sinten niku, ajeng napa, jeng ngengerke anak kula

Namine sinten, namine Dandang, nyambut gawe abot, napa inggih purun,purun

Anggere trima tak ingoni sego sakepel, sambel sak dulit, iwak sak cuwil, jangan setetes sandhang sak suwek, inggih purun waton angsal ngengeran

Dandang nyambut gawe lan tumandang, ya ya tung ya ya dang

Angon raja kaya ngumbahi sandangan wayah peteng lan padhang

Kula nuwun, sinten niku, nedha wangsul anak kula

Dhek isih kuru dingengerke, bareng wis lemu dijaluk bali, pun mang gawa

Boten trima,boten trima, anak kula disiya-siya

Untuk menyajikan sebuah gambar atau membuat sketsa-sketsa dalam penciptaan desain busana, ada beberapa cara yang masing-masing memiliki karakter dan tujuan yang berbeda-beda. Cara atau teknik penyajian gambar tersebut adalah design sketching, production sketching, presentation drawing dan fashion illustration.Teknik Fashion Illustration adalah suatu sajian gambar untuk tujuan promosi suatu desain, yang biasanya untuk suatu majalah, sampul depan atau cover buku, undangan, brosur, poster dan lainlain. Dibuat dengan menggunakan proporsi tubuh 9 kali atau 10 kali tinggi kepala dengan kaki dibuat lebih panjang (Kamil, 1986: 36-47). Pengertian proporsi tubuh secara illustrasi adalah ketentuan yang dipakai untuk menggambar ukuran tubuh manusia yang berpedoman pada ukuran panjang kepala. Dibuat secara illustrasi maksudnya kaki digambar lebih panjang dari badan (Widarwati et al., 1996: 3).Teknik pembuatan gambar yang disajikan pada kesempatan ini, menggunakan teknik pembuatan gambar secara 
illustrasi dengan ukuran $81 \frac{1}{2} \mathrm{X}$ tinggi kepala dengan tinggi kepala $3 \mathrm{~cm}$, panjang badan keseluruhan menjadi $31 \mathrm{~cm}$ karena setiap bagian ditambah 1 $\mathrm{mm}$. Secara tidak langsung atau dengan sendirinya panjang garis sumbu antara setiap bagian selisih $1 \mathrm{~mm}$, dan ukuran badan dilebarkan.

Untuk menilai hasil karya desain mahasiswa atau Ketrampilan Menggambar menggunakan indikator-indikator, yaitu: (1) Prespektif (proporsi tubuh manusia secara ilustrasi); (2) Komposisi (meliputi penerapan unsur-unsur dan prinsip-prinsip desain); (3) Kesatuan; (4) Variasi (termasuk kemampuan membuat variasi bentuk dari bentuk asli ke bentuk yang baru); (5) Warna; (6) Teknik Penyajian Gambar; (7) Teknik Penyelesaian Gambar; (8) Kesesuaian dengan sumber ide; (9) Kesesuaian kesempatan (Gorman, 1979: 360 \& Sawitri, 1992: 10).

Prespektif, dalam desain busana yang dimaksudkan dalam penelitian ini proporsi atau perbandingan tubuh manusia secara ilustrasi, dengan tinggi tubuh 9-12 kali tinggi kepala. Komposisi, meliputi penerapan unsur-unsur desain berupa garis, arah, bentuk, tekstur, warna, ukuran, nilai gelap terang dan penerapan prinsip-prinsip desain yang meliputi perbandingan, harmoni (keselarasan), kontras, pusat perhatian, keseimbangan dan irama. Kesatuan, adanya suatu pengulangan unsur desain, misalnya bentuk leher bulat dengan bentuk rok yang melingkar. Variasi, merupakan kemampuan mahasiswa dalam membuat bentuk-bentuk baru yang bervariasi dari bagian-bagian kostum, misalnya bentuk leher, kerah, lengan, rok, dan sebagainya. Warna, meliputi teknik pencampuran warna dan pemilihan warna. Teknik penyajian gambar, yaitu teknik yang digunakan untuk memperkenalkan/memperlihatkan gambar kepada orang lain atau pun untuk keperluan sendiri. Teknik penyelesaian gambar, yaitu cara menyelesaikan gambar desain kostum yang telah diciptakan di atas gambar proporsi tubuh, sehingga gambar tersebut dapat terlihat bahan dan permukaan tekstilnya, serta warna-warna yang dipakai, hiasan yang dikenakan seperti kancing, renda, lipit jarum, saku yang ditempel, dan sebagainya. Kesesuaian dengan sumber ide, yaitu adanya kesesuaian antara gambar desain kostum yang diciptakan dengan sumber yang menjadi inspirasinya. Kesuaian dengan kesempatan, yaitu cocok tidaknya garis desain yang dibuat, bahan dan warna yang dipilih untuk keperluan gambar desain kostum yang diciptakan.

Untuk memberi gambaran kepada pembaca, penulis mencoba mengaplikasikannya dalam beberapa sajian gambar karya Afif Ghurub Bestari, staf pengajar Desain Busana di Prodi Pendidikan Teknik Busana FT UNY. 


\section{Gambar $1 \quad$ Gambar $2 \quad$ Gambar 3}

Keterangan Gambar :

Gambar 1: Desain Busana Wanita dengan sumber ide lagu Cublakcublak Suweng. Terlihat pada gambar hiasan bentuk-bentuk yang membulat pada scarf, kamisol dan rok yang diambil dari batu kecil yang digunakan dalam permainan Cublak-cubblak Suweng. Kamisol merupakan pengembangan bentuk kemben yang digunakan oleh wanita Jawa. Desain ini berkesan feminin dan anggun.

Gambar 2: Desain Busana Wanita dengan sumber ide lagu Jaranan. Tampak dalam desain ujung rok yang menyerupai bentuk ekor kuda, kebaya yang sudah dimodifikasi dengan bentuk krah menyerupai palana kuda dan pemakaian kamisol untuk busana dalam. Desain ini berkesan maskulin, klasik dan unik.

Gambar 3 : Desain Busana Wanita dengan sumber ide lagu Soyang. Dalam desain ini terlihat perpaduan antara bentuk kebaya, kemben, dan pemakaian selendang yang diselipkan menjadi perpaduan yang berkesan simple dan tidak merepotkan.Rok panjang yang terbelah di bagian depan merupakan modifikasi dari pemakaian kain panjang yang dirancang agar bebas bergerak.Desain ini berkesan feminin dan elegan.

\section{PENUTUP}

Demikian akhir penulisan tentang penciptaan desain busana wanita yang mengambil ide dari lagu-lagu dolanan, sebagai media dalam pembelajaran berbasis budaya. Pembelajaran Berbasis Budaya merupakan alat bagi proses belajar untuk memotivasi dalam mengaplikasikan pengetahuan, mempersepsikan keterkaitan antara berbagai bidang ilmu, sebagai strategi untuk mendorong proses imajinatif, berpikir kreatif dan sadar budaya. Harapan dari pembelajaran ini adalah untuk memperoleh 
pengalaman yang tidak asing di komunitas budayanya sendiri, menjadikan proses pembelajaran untuk bereksplorasi bagi mahasiswa maupun bagi tenaga pengajar dalam mencari strategi dan perkembangan ketrampilan menggambar khususnya dan sekaligus mengapresiasikan karya seni. Ketrampilan berkarya seni dan berbudaya mendorong terjadinya proses pembelajaran lebih bermakna. Penulis menyadari dengan sungguh bahwa tulisan ini masih jauh dari sempurna, oleh karena itu kritik dan saran yang membangun sangat diharapkan untuk kesempurnaan tulisan ini. Disertai harapan, semoga tulisan yang sedikit ini mempunyai makna yang besar bagi orang lain yang memerlukannya. Semoga Bermanfaat.

\section{DAFTAR RUJUKAN}

Chodiyah \& Wisri A. Mamdy. (1982), Disain Busana, Jakarta, Dikmenjur Depdikbud

Daradjatun, Nunun \& Samuel Watimena. (2003), Inspirasi Mode Indonesia, Jakarta, Yayasan Buku Bangsa bekerja sama dengan Gramedia Pustaka Utama

Dharsono, Harry. "Tata Busana dan Penampilan", Makalah Seminar Sehari yang diselenggarakan Lippo Bank Solo, 1992

Gorman, R.M. (1974), The psychology of Classroom Lerarning, Columbus, Ohio: Charles, E. Merril

Kamil, Sri Ardiati. (1986), Fashion Design, Jakarta, CV Baru

Krisdyatmiko (ed.) (1999), Dolanan Anak: Refleksi Budaya dan Wahana Tumbuh Kembang Anak, Yogyakarta, Plan International Indonesia

Mardjono, Hariani. "Busana Nan Serasi Menampilkan Kharisma Nan Mempesona", Makalah Seminar Kecantikan Tiara Kusuma Fair, 1991

Marsono, Hendrosaputro, Suwandi \& Melati Listyorini. 1999), Berbagai Permainan Tradisional Masyarakat Jawa, Yogyakarta, Lembaga Studi Jawa Bekerja sama dengan Plan Internasional Indonesia

Munandar, S.C.U. (1987), Mengembangkan Bakat dan Kreativitas Anak Sekolah, Jakarta, Gramedia

Naibaho, T. (1985), Teknik Evaluasi Karya Seni, Jakarta, Proyek Peningkatan dan Pengembangan Perguruan Tinggi IKIP Jakarta

Pannen, Paulina. ((Maret 2004), "Seni dan Budaya Dalam Pembelajaran Berbasis Budaya " dalam SENI, Jurnal Pengetahuan dan Penciptaan Seni, X/01, BP ISI Yogyakarta

Poerwadarminta,W.J.S. (1939), Baoesastra Djawa, Groningen Batavia, J.B. Wolters' Uitgevers'Maatschappij 
Prawiroatmodjo,S. (1957), Bausastra Djawa-Indonesia, Surabaya,Express \& Marfiah

Sawitri, Sicilia, Widyabakti Sabatari \& Sri Widarwati. (1983), Rencana Kegiatan Belajar Mengajar Desain Busana Lanjut, Yogyakarta, PKK FPTK Yogyakarta

Semiawan, Conny. (1987), Memupuk Bakat dan Kreativitas Siswa Sekolah Menengah, Jakarta, Gramedia

Soedarsono, Retno Astuti \& Pantja Sunjata, I.W. (1986), Beberapa Aspek Kebudayaan Jawa, Yogyakarta, Depdikbud Dirjend Kebudayaan Proyek Penelitian dan Pengkajian Kebudayaan Nusantara (Javanologi)

Soedarsono (ed.) (1986), Kesenian, Bahasa dan Foklor Jawa, Yogyakarta, Depdikbud Dirjend Kebudayaan Proyek Penelitian dan Pengkajian Kebudayaan Nusantara (Javanologi)

Sudaryanto \& Pranowo (ed.) (2001), Kamus Pepak Basa Jawa, Yogyakarta, Badan Pekerja Konggres Bahasa Jawa

Suharyadi, A.A. (1989), Dasar-dasar Desain Busana, Jakarta, Nina Dinamika

Sulistio, Hartatiati. (2006), Rancang Busana : Terampil Membentuk Pribadi Mempesona, Semarang, UNNES Press

Supriadi, Dedi. (1994), Kreativitas, Kebudayaan \& Perkembangan Iptek, Bandung, Alfabeta

Sternberg, Robert J. (1999), Handbook of Creativity, New York, Cambridge University Press

Tashadi, (1982), Permainan Rakyat Daerah Istimewa Yogyakarta, Yogyakarta, Depdikbud Proyek Inventarisasi dan Dokumentasi Kebudayaan Daerah

(1983), Permainan Anak-anak Daerah Istimewa Yogyakarta, Yogyakarta, Depdikbud Proyek Inventarisasi dan Dokumentasi Kebudayaan Daerah

Tim Pustaka Widyatama. (2006), Mengenal Lagu-lagu Daerah, Alat Musik Tradisional, Pakaian Adat dan Tarian Daerah, Yogyakarta, Pustaka Widyatama

Wibowo, H.J. Supanto, Pramono \& Moeljono. (1990), Pakaian Adat Tradisional Daerah Istimewa Yogyakarta, Jakarta, Depdikbud Dirjend Kebudayaan Direktorat Sejarah dan Nilai Tradisional Proyek Inventarisasi dan Pembinaa Nilai-nilai Budaya

Widarwati, Sri, Widyabakti Sabatari \& Sicilia Sawitri. (1996), Disain Busana II, Yogyakarta, IKIP Yogyakarta

Widyatmanta, Siman. (2002), Berbahasa Jawa : Untuk Pelayanan Gerejawi dan Masyarakat, Yogyakarta, Taman Pustaka Kristen 